\title{
Perbedaan Hasil Belajar Siswa Menggunakan Model Numbered Head Together Dengan Snowball Throwing Materi Sistem Indera Kelas XI SMA Prayatna Medan Tahun Pembelajaran 2016/2017
}

\author{
Yusri Fefiani $^{(1)}$ Hermalisa Surbakti $^{(2)}$ \\ ${ }^{(1)}$ Dosen PNS DPK Kopertis Prodi Pendidikan Biologi FKIP Universitas Islam Sumatera Utara \\ ${ }^{(2)}$ Alumni Program Studi Pendidikan Biologi FKIP-Universitas Islam Sumatera Utara \\ yusrifefiani@fkip.uisu.ac.id ${ }^{(1)}$, surbaktilisa@yahoo.com ${ }^{(2)}$
}

\begin{abstract}
ABSTRAK
Penelitian ini dilakukan untuk mengetahui perbedaan hasil belajar siswa yang diajar dengan menggunakan model pembelajaran Numbered Head Together dengan siswa yang diajar menggunakan model pembelajaran Snowball Throwing pada materi Sistem Indra di kelas XI SMA Prayatna Medan Tahun Pembelajaran 2016/2017. Penelitian ini merupakan penelitian eksperimen dan data diperoleh dari dua kelas yang dipilih secara purposive sampling. Waktu penelitian ini dilaksanakan pada bulan Mei s/d Juni. Populasi dalam penelitian ini adalah seluruh siswa kelas XI.Sampel penelitian ini sebanyak 2 kelas yaitu kelas eksperimen I yang diajarkan dengan menggunakan model Numbered Head Together dan kelas eksperimen II yang diajarkan dengan menggunakan model Snowball Throwing. Sebagai alat pengumpul data hasil belajar digunakan tes objektif yang berjumlah 30 soal yang telah teruji validitas, reabilitas, tingkat kesukaran, dan daya beda soalnya. Hasil pengolahan data diperoleh rata-rata post-test kelas eksperimen I (Numbered Head Together) adalah 71,4 dan rata-rata pos-test kelas eksperimen II (Snowball Throwing) adalah 69,4. Semua data pos-test diperoleh data bedistribusi normal. Data tersebut kemudian diuji homogenitas sehingga diketahui kedua kelas homogen. Setelah diberi post-test nilai rata-rata hasi belajar pada kelas eksperimen I adalah sebesar 71,4 dan pada eksperimen II diperoleh rata-rata hasil belajar sebesar 69,4. Dari data tersebut setelah dianalisis, maka diperoleh peningkatan hasil belajar siswa kelas eksperimen I adalah sebesar 54,2\% dan peningkatan hasil belajar siswa kelas eksperimen II adalah sebesar 45,7\%. Sehingga dapat diketahui bahwa terdapat perbedaan peningkatan hasil belajar biologi siswa yang diajar dengan menggunakan model pembelajaran Numbered Head Together dan model pembelajaran Snowball Throwing.
\end{abstract}

Kata kunci : eksperimen, model pembelajaran, hasil belajar, perbedaan

\section{PENDAHULUAN}

Belajar pada hakikatya adalah proses interaksi terhadap semua situasi yang ada di sekitar idividu. Belajar dapat dipandang sebagai proses yang diarahkan kepada tujuan dan proses berbuat melalui berbagai pengalaman.Belajar juga merupakan proses melihat, mengamati, dan memahami sesuatu. Sudjana dalam (Rusman, 2016:1). Kegiatan pembelajaran dilakukan oleh dua orang pelaku, yaitu guru dan siswa. Perilaku guru adalah mengajar dan perilaku siswa adalah belajar. Hubungan antara guru, siswa, dan bahan ajar bersifat dinamis dan kompleks. Untuk mencapai keberhasilan dalam kegiatan pembelajaran, terdapat beberapa komponen yang dapat menunjang yaitu komponen tujuan, komponen materi, komponen strategi belajar mengajar, dan komponen evaluasi. Belajar mengajar adalah suatu kegiatan yang bernilai edukatif. Nilai edukatif mewarnai interkasi yang terjadi antara guru dengan anak didik. Interkasi yang bernilai edukatif dikarenakan kegiatan belajar mengajar yang dilakukan diarahkan untuk mencapai tujuan tertentu yang telah dirumuskan sebelum pengajaran dilakukan. Namun pada kenyataannya kegiatan belajar mengajar tidak seperti yang diharapkan. Banyak faktor yang mempengaruhi hal tersebut, diantaranya metode yang digunakan guru tidak bervariasi, sarana prasarana yang tidak 
Hermalisa S, Yusri Fefiani : Perbedaan Hasil Belajar Siswa Menggunakan Model Numbered Head Together Dengan Snowball Throwing Materi Sistem Indera Kelas XI SMA Prayatna Medan Tahun Pembelajaran 2016/2017

mendukung, kurangnya minat belajar siswa dan sebagainya. Berdasarkan hasil wawancara yang dilakukan peneliti dengan salah satu guru mata pelajaran Biologi yang dilakukan pada bulan Maret 2017 di SMA Swasta Prayatna Medan ialah, SMA Prayatna Medan merupakan salah satu sekolah swasta menengah atas yang terletak di kecamatan Medan Tembung, tepatnya di jalan Letda Sudjono No. 403 Sumatera Utara, Medan. Sekolah ini dipimpin oleh Ibu Suriyati Tanjung. Sekolah ini menggunakan Kurikulum Tingkat Satuan Pendidikan (KTSP). Adapun fasilitas yang ada di SMA Prayatna Medan ialah kelas, ruangan bimbingan konseling, lab. Biologi, ruang kesenian, lapangan basket, lapangan sepak bola, lapangan voli, perpustakaan, parkir mobil, parkir kreta, uks, kantin, dan aula/ruang serbaguna. Dari wawancara tersebut, guru mata pelajaran biologi (Ibu Risma S.Pd) mengatakan bahwa Kriteria Ketuntasan Minimum ( KKM) yang ditetapkan adalah 75 dan rata-rata nilai harian ulangan biologi siswa hanya $40 \%$ yang mencapai Kriteria Ketuntasan Minimum dan 60\% yang tidak mencapai Kriteria Ketuntasan Minimum. Dalam penyampaian materi pembelajaran biologi masih menggunakan metode kurang bervariasi dan metode konvensional karena metode ini sangat mudah untuk digunakan, serta kurangnya fasilitas belajar mengajar salah satunya ialah keterbatasan alat bantu Infokus sehingga menyebabkan siswa kurang tertarik, bersikap pasif, malas untuk bertanya, jenuh dalam belajar dan tidak fokus pada materi yang disampaikan oleh guru. Oleh karena itu, melalui penelitian ini penulis bermaksud memberikan informasi kepada guru tentang model-model pembelajaran baru yang bisa diterapkan dalam pembelajaran Biologi. Dalam penelitian ini penulis menggunakan model Numbered Head Together dan Snowball Throwing untuk diujikan. Menurut Joyce dan Weil dalam Rusman (2016:133) model pembelajaran diartikan suatu rencana atau pola yang dapat digunakan untuk membentuk kurikulum (rencana pembelajaran jangka panjang), merancang bahan-bahan pembelajaran, dan membimbing pembelajaran di kelas. Saat ini telah banyak dikembangkan model pembelajaran, diantaranya NHT dan Snowball Throwing. Kagen dalam Trianto (2016:82) menyatakan bahwa Numbered Head Together adalah salah satu dari strategi pembelajaran kooperatif yang dirancang untuk mempengaruhi pola interaksi siswa dan sebagai alternatif terhadap struktur kelas tradisional. Model pembelajaran NHT ini secara tidak langsung melatih siswa untuk saling berbagi informasi, mendengarkan dengan cermat, sehingga siswa lebih produktif dalam pembelajaran. Miftahul (2014:226) model pembelajaran Snowball Throwing merupakan pembelajaran yang diadopsi pertama kali dari game fisik di mana segumpalan salju dilempar dengan maksud memukul orang lain. Dalam konteks pembelajaran, Snowball Throwing diterapkan dengan melempar segumpalan kertas untuk menunjuk siswa yang diharuskan menjawab soal dari guru. Di samping itu dapat membangkitkan keberanian siswa dalam mengemukakan pertanyaaan dengan tuntunan pertanyaan kepada teman lain maupun guru. Juga melatih siswa menjawab pertanyaan yang diajukan oleh temannya dengan baik. Sistem Indera merupakan materi pokok yang dipelajari di kelas XI SMA semester II. Materi Sistem Indra adalah materi yang cukup penting dalam mempelajari pelajaran biologi. Dalam materi Sistem Indra banyak mengandung konsep sehingga sukar dipahami oleh siswa. Untuk itu diperlukan model dan metode pembelajaran yang dapat menciptakan suasana yang menyenangkan agar siswa dapat lebih memahami pelajaran Sistem Indera. Dengan memberikan model pembelajaran koooperatif tipe NHT dan Snowball Throwing pada materi pokok Sistem Indera diharapkan akan memberikan variasi terhadap penggunaan metode pembelajaran yang dapat menciptakan suasana yang menyenangkan serta tidak membosankan sehingga aktivitas dan hasil belajar biologi siswa lebih meningkat. 
Hermalisa S, Yusri Fefiani : Perbedaan Hasil Belajar Siswa Menggunakan Model Numbered Head Together Dengan Snowball Throwing Materi Sistem Indera Kelas XI SMA Prayatna Medan Tahun Pembelajaran 2016/2017

\section{METODE PENELITIAN}

Langkah-langkah yang dalam penelitian ini adalah sebagai berikut:

\section{Persiapan Penelitian uji coba instrumen}

a. Melakukan observasi awal ke sekolah untuk mengetahui masalah yang terjadi dalam proses pembelajaran khususnya di kelas XI tentang pelajaran biologi dan metode pembelajarannya.

b. Penyusunan proposal penelitian

c. Persetujuan proposal penelitian

d. Mengurus surat ijin penelitian

e. Konsultasi dengan kepala sekolah tempat penelitian dilaksanakan dengan membawa surat izin penelitian

f. Konsultasi dengan guru biologi kelas XI

g. Menyusun materi pembelajaran dengan menerapkan model pembelajaran Numbered Head Together dengan Snowball Throwing

h. Menyusun evaluasi belajar siswa

2. Tahap Pelaksanaan

a. Untuk Kelas Numbered Head Together

1. Menjelaskan tujuan pembelajaran dan memotivasi siswa

2. Menjelaskan materi ajar secara ringkas pada materi Sistem Indera di kelas XI

3. Membagi kelompok siswa yang terdiri dari beberapa siswa heterogen dan memberi mereka nomor, sehingga tiap siswa dalam tim tersebut memiliki nomor yang berbeda

4. Membagi lembar kerja siswa kepada setiap kelompok. Para siswa berpikir bersama untuk menggambarkan dan meyakinkan bahwa tiap orang mengetahui jawaban tersebut.

5. Guru menyebutkan suatu nomor dan para siswa dari tiap kelompok dengan nomor yang sama mengangkat tangan dan menyiapkan jawaban untuk seluruh kelas dan mempresentasikan jawaban mereka di depan kelas

6. Guru memberi kesimpulan dari hasil jawaban siswa

7. Guru memberikan penghargaan kepada setiap siswa yang menjawab dengan benar.

8. Evaluasi

9. Penutup

10. Setelah selesai pembelajaran kemudian guru memberikan post-test kepada siswa untuk mengetahui ketercapaian penerapan pembelajaran model kooperatif tipe Numbered Head Together

11. Mengumpulkan data-data hasil penelitian.

12. Menganalisis data dan menyusun hasil penelitian

13. Menarik kesimpulan dari data hasil penelitian.

b. Untuk kelas Snowball Throwing

1. Menjelaskan tujuan pembelajaran dan memotivasi siswa

2. Guru menyampaikan materi yang akan disajikan

3. Guru membentuk kelompok-kelompok dan memanggil masing-masing ketua kelompok untuk memberikan penjelasan tentang materi Sistem Indra

4. Masing-masing ketua kelompok kembali ke kelompoknya masing-masing, kemudian menjelaskan materi yang disampaikan oleh guru kepada temannya.

5. Kemudian masing-masing siswa diberikan satu lembar kertas kerja, untuk menuliskan satu pertanyaan apa saja yang menyangkut materi yang sudah dijelaskan oleh ketua kelompok. 
Hermalisa S, Yusri Fefiani : Perbedaan Hasil Belajar Siswa Menggunakan Model Numbered Head Together Dengan Snowball Throwing Materi Sistem Indera Kelas XI SMA Prayatna Medan Tahun Pembelajaran 2016/2017

6. Kemudian kertas berisi pertanyaan tersebut dibuat seperti bola dan dilempar dari satu siswa ke siswa yang lain.

7. Setelah siswa mendapat satu bola/satu pertanyaan diberikan kesempatan kepada siswa untuk menjawab pertanyaan yang tertulis dalam kertas berbentuk bola tersebut secara bergantian.

8. Penutup

9. Setelah selesai pembelajaran kemudian memberikan post-test kepada siswa untuk mengetahui ketercapaian penerapan Model pembelajaran Snowball Throwing.

10. Mengumpulkan data-data hasil penelitian

11. Menganalisis data dan menyusun hasil penelitian.

12. Menarik kesimpulan dari data hasil penelitian.

\section{Teknik Analisis Data}

Dalam penelitian ini, teknik analisis data dilakukan sebagai berikut:

Mentabulasi data (nilai) dari kelas sample.

1. Menghitung nilai rata - rata (mean) dari masing - masing kelas dengan rumus

Sudjana (2014: 67), sebagai berikut:

$$
-X=\frac{\sum f i x i}{\sum f i}
$$

Keterangan :

$$
\begin{aligned}
{ }^{-} X & =\text { Nilai rata-rata } \\
\mathrm{Fi} & =\text { Frekuensi nilai } \\
\mathrm{Xi} & =\text { Jumlah nilai siswa }
\end{aligned}
$$

2. Menghitung standar deviasi

Menurut Sudjana (2014 : 95), menghitung Standar deviasi, melalui rumus varians sebagai berikut:

$S^{2}=\frac{n \sum f i x i 2-\left(\sum f i x i\right) 2}{n(n-1)}$

Keterangan :

$$
\begin{aligned}
S^{2} & =\text { varians } \\
n & =\text { jumlah seluruh siswa } \\
\mathrm{fi} & =\text { jumlah frekuensi siswa } \\
\mathrm{xi} & =\text { nilai ke-1 yang diperoleh }
\end{aligned}
$$

1. Pengujian Hipotesis menurut Sudjana (2014 : 239), sebagai berikut:

$$
t=\frac{\left(\bar{x}_{1}-\bar{x}_{2}\right)}{s \sqrt{\frac{1}{n_{1}}+\frac{1}{n_{2}}}}
$$

Keterangan:

$\mathrm{T}=$ Distribusi $\mathrm{t}$

$\bar{x}_{1}=$ Skor rata-rata nilai siswa kelas Numbered Head Together

$\bar{x}_{2}=$ Skor rata-rata nilai siswa kelas Snowball Throwing

$\mathrm{n}_{1}=$ Jumlah siswa kelas Numbered Head Together

$\mathrm{n}_{2} \quad=$ Jumlah siswa kelas Snowball Throwing

$\mathrm{S}=$ Varians gabungan 
Hermalisa S, Yusri Fefiani : Perbedaan Hasil Belajar Siswa Menggunakan Model Numbered Head Together Dengan Snowball Throwing Materi Sistem Indera Kelas XI SMA Prayatna Medan Tahun Pembelajaran 2016/2017

Dimana, untuk menghitung Varians gabungan digunakan rumus Sudjana (2014 : 239), sebagai berikut :

$$
S^{2}=\frac{\left(n_{1}-1\right) S_{1}^{2}+\left(n_{2}-1\right) S_{2}^{2}}{\left(n_{1}+n_{2}\right)-2}
$$

Keterangan :

$\mathrm{S}^{2}=$ Varians gabungan

$\mathrm{n}_{1}=$ Jumlah siswa kelas Numbered Head Together

$\mathrm{n}_{2}=$ Jumlah siswa kelas Snowball Throwing

$\mathrm{S}_{1}=$ Simpangan baku/standart deviasi nilai kelasNumbered Head Together

$\mathrm{S}_{2}=$ Simpangan baku/standart deviasi nilai kelas Snowball Throwing

Setelah memperoleh nilai $t_{\text {hitung }}$ maka dicari nilai $t_{\text {tabel }}$ dimana :

$\mathrm{t}_{\text {tabel }}=\left(\mathrm{t}_{(1-1 / 2 \alpha)} ; \mathrm{dk}\right)$

$\mathrm{dk}=\left(\mathrm{n}_{1}+\mathrm{n}_{2}-2\right)$

Selanjutnya nilai thitung dibandingkan dengan nilai ttabel dengan ketentuan :

$\mathrm{H}_{0}$ diterima $\left(\mathrm{H}_{\mathrm{a}}\right.$ ditolak $)$ apabila $\mathrm{t}_{\text {hitung }}<\mathrm{t}_{\text {tabel }}$

$\mathrm{H}_{0}$ ditolak $\left(\mathrm{H}_{\mathrm{a}}\right.$ diterima $)$ apabila $\mathrm{t}_{\text {hitung }}<\mathrm{t}_{\text {tabel }}$

\section{HASIL PENELITIAN}

Setelah mempelajari Sistem Indera menggunakan model Numbered Head Togetherpadakelas XI IPA-3 SMA Prayatna Medan Tahun Pembelajaran 2016/2017, selanjutnya diberikan test berupa post-testsehingga diperoleh nilai tertinggi siswa adalah 90 dengan jumlah siswa yang memperoleh nilai tersebut adalah 3 orang, sedangkan nilai terendah yang diperoleh siswa adalah 50 dengan jumlah I orang. Berdasarkan nilai Kriteria Ketuntasan Minimal (KKM) di sekolah yang diteliti yaitu 75,00. Nilai post-test siswa terjadi peningkatan yaitu siswa yang tuntas sebanyak 19 orang ( $54 \%$ ) dan 16 orang $(45 \%)$ dinyatakan tidak tuntas. Sebelum uji persyaratan data, dilakukan perhitungan untuk mengetahui nilai rata-rata dan simpangan baku post-test. Dari hasil distribusi untuk $\alpha=$ 0,05 dan $\mathrm{dk}=\mathrm{n} 1+\mathrm{n} 2-2(35+35-2=68)$ diperoleh $\mathrm{t}_{\text {tabel }}=1,998$ dan $\mathrm{t}_{\text {hitung }}=0,694$. Jika nilai $t_{\text {hitung }}$ dibandingkan dengan $t_{\text {tabel }}$ maka $t_{\text {hitung }}>t_{\text {tabel }}=0,694>1,998$ sehingga $H_{a}$ diterima dan $\mathrm{H}_{\mathrm{O}}$ ditolak. Dengan demikian dapat disimpulkan ada perbedaan yang signifikan dari hasil belajar siswa yang menggunakan model Numbered Head Together dengan Snowball Throwingpada materi Sistem Indra pada siswa kelas XI SMA Prayatna Medan Tahun Pembelajaran 2016/2017. ( perhitungan terdapat pada lampiran 22 halaman 158 ). Penerimaan $\mathrm{H}_{\mathrm{a}}$ dapat digambarkan melalui kurva di bawah ini:

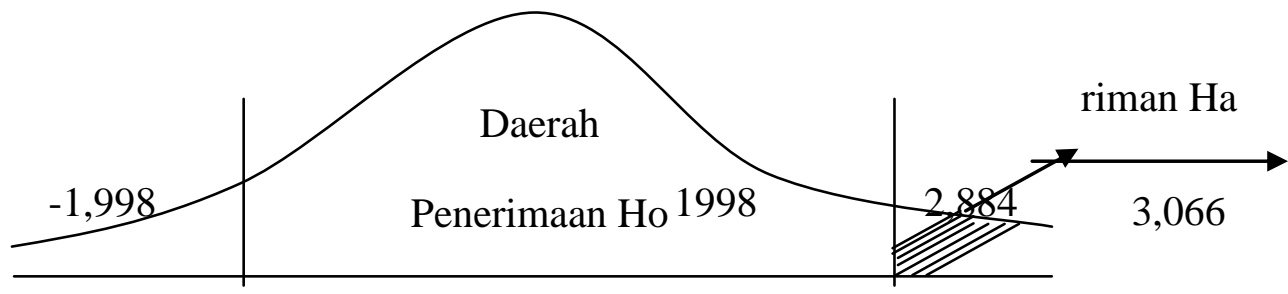

\section{Gambar: Kurva Pengujian Hipotesis Penelitian}


Hermalisa S, Yusri Fefiani : Perbedaan Hasil Belajar Siswa Menggunakan Model Numbered Head Together Dengan Snowball Throwing Materi Sistem Indera Kelas XI SMA Prayatna Medan Tahun Pembelajaran 2016/2017

\section{KESIMPULAN}

Berdasarkan uraian penelitian diatas maka dapat diambil beberapa kesimpulan, yaitu:

1. Berdasarkan nilai rata-rata hasil belajar siswa pada kelas XI IPA-3 yang menggunakan model Numbered Head Together adalah 71,4, dengan persentase ketuntasan yaitu 19 siswa yang tuntas $54,2 \%$ dan yan tidak tuntas sebanyak 16 siswa. Sedangkan nilai rata-rata hasil belajar pada siswa kelas XI IPA-4 yang menggunakan model Snowball Throwing adalah 69,4 dengan persentase ketuntasan yaitu 16 siswa ( 45,7\%) dengan demikian dapat dikatakan bahwa terdapat perbedaan hasil belajar pada kedua kelas tersebut.

2. Berdasarkan uji hipotesis dalam penelitian ini yaitu Ha diterima dan Ho ditolak dengan nilai diperoleht $t_{\text {hitung }}>t_{\text {tabel }}$ yaitu $2,884>1,998$. Maka dari hasil analisis terhadap rumusan hipotesis menunjukkan bahwa ada pengaruh yang signifikan penggunaan model Numbered Head Together dengan Snowball Throwing pada materi Sistem Indra Kelas XI SMA Prayatna Medan Tahun Pembelajaran 2016/2017

\section{SARAN}

Beberapa saran yang diusulkan berdasarkan penelitian, maka peneliti memberikan beberapa saran yaitu :

1. Penggunaan model Numbered Head Together dengan Snowball Throwing sebagai salah satu solusi untuk meningkatkan hasil belajar siswa.

2. Diharapkan bagi siswa dapat mempermudah untuk memahami dan menerima materi pembelajaran biologi khususnya pada materi Sistem Indera

3. Bagi peneliti (calon guru) sebagai bahan persiapan diri menjadi guru dan menambah wawasan peneliti tentang proses belajar mengajar dengan menggunakan model Numbered Head Together

\section{DAFTAR PUSTAKA}

Al-Qur'an surah Al-Baqarah ayat 151

Arikunto, Suharsimi. (2012). Dasar-Dasar Evaluasi Pendidikan. Jakarta: Bumi Aksara

Huda, Miftahul. (2014). Model- Model Pengajaran dan Pembelajaran. Yogyakarta: Pustaka Belajar

http://genggaminternet.com//bagian-bagianmata.com diakses 22 juni 2015

http://www.penyakitmata.org diakses 10 maret 2015

http://www.soft/ilmu.com/2015/04/pembagiantelinga.com diakses 04 maret 2015

htttp://www.soft/ilmu.com/2015/04/pembagianhidung.com diakses 04 maret 2015

http://aktomisriadi.blogspot.co.id diakses 25 januari 2013 
Hermalisa S, Yusri Fefiani : Perbedaan Hasil Belajar Siswa Menggunakan Model Numbered Head Together Dengan Snowball Throwing Materi Sistem Indera Kelas XI SMA Prayatna Medan Tahun Pembelajaran 2016/2017

http://www.google.com/search?q=Gambar+Lidah+Serta+Bagiannya diakses 11 april 2013

http://www.gardapengetahuan.xyz/2013/02beberapa-fungsi-bagiankulit.html diakses 02 april 2013

http://fembeisma.wordpress.com/science/sistemkoordinasi-Manusia/sistem-indera manusia2017 diakses 23 juni 2017

Karmana, Oman. (2008), Cerdas Belajar Biologi Kelas XI SMA/MA. Bandung: PT Multi Printindo Persada

Muhibbin, (2010). Psikologi Pendidikan. Bandung: PT Remaja Rosdakarya

Nurhayati, Nunung dkk. 2014 Biologi 1700 Bank soal bimbingan pemantapan Bandung: Yrama widya

Prawirohartono, Slamet dan Hidayati, Sri. (2012). Sains Biologi SMA/MA Kelas XI. Jakarta: Bumi Aksara

Pratiwi , D. A, et.al. 2012. Biologi SMA/MA Kelas XI. Jakarta: PT Gelora Aksara Pratama

Riandari, Henny. (2012). Biologi SMA/MA Kelas XI. Solo: PT Tiga Serangkai Pustaka Mandiri

Rusman, (2016). Model-Model Pembelajaran. Jakarta: PT RajaGrafindo Persada

Shoimin, Aris (2013). Model Pembelajaran Inovatif dalam kurikulum 2013. Yogyakarta: Ar-Ruzz Media.

Sudjana, (2014). Metode Statistika. Bandung. PT Tarsito.

Suyanto dan Jihad, Asep. (2013). Menjadi Guru Profesional. Jakarta: Erlangga Group

Trianto, (2009). Mendesain Model Pembelajaran Inovatif- Progresif. Jakarta: Kencana 